\title{
Exercise acutely increases vitamin $D$ receptor expression in T lymphocytes in vitamin D-deficient men, independent of age
}

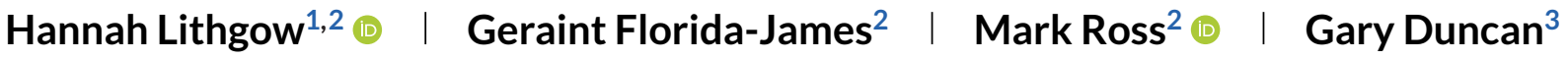 \\ Melanie Leggate ${ }^{2}$
}

${ }^{1}$ Institute of Cardiovascular \& Medical Sciences, University of Glasgow, Glasgow, UK

${ }^{2}$ School of Applied Sciences, Edinburgh Napier University, Edinburgh, UK

${ }^{3}$ Rowett Institute of Nutrition and Health, University of Aberdeen, Aberdeen, UK

\section{Correspondence}

Hannah Lithgow, Institute of Cardiovascular \& Medical Sciences, University of Glasgow, 126 University Place, Glasgow G12 8TA, UK.

Email: hannah.lithgow@glasgow.ac.uk

Funding information

Edinburgh Napier University

Edited by: Joanne Murray

\begin{abstract}
Vitamin D plays a key role in the modulation of the immune system, mediated through the intracellular vitamin D receptor (VDR). Exercise has been shown to influence the activity and availability of the VDR. The aim of this study was to investigate the effect of age on basal immune cell (T-lymphocyte) VDR expression and the subsequent effect of acute aerobic exercise to modulate VDR expression in peripheral T cells. Thirty-five men were included in the study (mean \pm SD: age $44 \pm 17$ years and body mass index $\left.25.7 \pm 3.1 \mathrm{~kg} / \mathrm{m}^{2}\right)$, separated into three age groups: $18-30(n=12), 31-45(n=11)$ and 60-75 years $(n=12)$. Participants completed two trials [control (CON) and aerobic exercise (AE)], with blood samples collected pre- and postexercise (0, 1 and $3 \mathrm{~h}$ ). Peripheral blood $T$ cells were isolated and analysed for VDR expression by flow cytometry. The results show that advanced age is associated with lower VDR expression in T cells ( $882 \pm 274,796 \pm 243$ and $594 \pm 174$ geomean in the 18-30, 31-45 and 60-75 year age groups, respectively). Acute AE was successful at acutely increasing VDR expression in T cells, irrespective of age. Advanced age corresponds to a lower T-cell VDR expression, which might be responsible for age-associated development of chronic conditions and autoimmunity. Exercise was successful in increasing VDR expression in T cells irrespective of age and independent of exercise-induced T-cell mobilization.

KEYWORDS

ageing, exercise, vitamin $\mathrm{D}$, vitamin $\mathrm{D}$ receptor
\end{abstract}

\section{1 | INTRODUCTION}

Several tissues and cell types have been identified in the literature as vitamin D active (Wang et al., 2012). Vitamin $D_{3}$ is an important secosteroid hormone derived from direct sunlight exposure [ultraviolet (UV) B radiation] and dietary sources (Holick \& Chen, 2008). It is classically regarded as a key regulator in bone health, playing a role in calcium and phosphate homeostasis. However, there is increasing evidence of the non-calcaemic and extraskeletal roles of vitamin D, specifically its role in the immune system. Although 25hydroxyvitamin $\mathrm{D}_{3}\left[25(\mathrm{OH}) \mathrm{D}_{3}\right]$ is used as the biomarker for vitamin $\mathrm{D}$ status, it is the biologically active form of vitamin $\mathrm{D}, 1,25(\mathrm{OH})_{2} \mathrm{D}_{3}$, and the vitamin D receptor (VDR) that provide the functional platform for vitamin D metabolism (Haussler et al., 1998). There is a nuclear intake of $1,25(\mathrm{OH})_{2} \mathrm{D}_{3}$ by T lymphocytes (Veldman et al., 2000), accompanied by a significant expression of the VDR in activated cells but not in isolated resting human T cells (Baeke et al., 2010; Provvedini et al., 1983). The binding of $1,25(\mathrm{OH})_{2} \mathrm{D}_{3}$ to the VDR in immune cells leads 
to the secretion of the antimicrobial peptide cathlicidin, which plays an important role in innate immune defences (Hewison, 2012). Moreover, $T$ cells may require expression of the VDR in order to regulate the T-cell effector response (Kongsbak et al., 2013). Therefore, vitamin D has an important role in modulating immune health and function.

A dysregulated immune system accompanies advancing age, thereby increasing susceptibility to infectious diseases and autoimmune conditions, and thus ill health (Yamshchikov et al., 2009). This dysregulated status of the immune system is referred to as immunosenescence, with older adults reported to display a greater number of senescent T cells than younger counterparts (Simpson et al., 2007). Senescent $T$ cells are associated with altered receptor expression (Mo et al., 2003). Although there are few data on the effects of age on baseline expression of VDR, Bischoff-Ferrari et al. (2004) reported that VDR protein expression decreases in human skeletal muscle tissue as age advances (Bischoff-Ferrari et al., 2004), which is in contrast to a study by Coleman et al. (2016) reporting no association between mRNA expression of VDR in T cells and age (Coleman et al., 2016). The disagreement between studies might be attributable to tissue-specific expression or the age of the population pools (24-91 vs. $\geq 50$ years, respectively). Therefore, the aim of the present study was to compare baseline T-cell VDR expression in young and older adults.

Emerging data are now suggestive that acute exercise can be an efficient stimulus to upregulate $25(\mathrm{OH}) \mathrm{D}_{3}$ concentrations in a human population (Sun et al., 2017) and upregulate intramuscular VDR and related enzyme expression in rats (Makanae et al., 2015). Longterm exercise might also promote vitamin $\mathrm{D}$ metabolism through the upregulation of intracellular VDR, albeit in skeletal muscle tissue (Aly et al., 2016; Bass et al., 2020). It is well established that immune cells, specifically $T$ cells, are highly responsive to exercise, with rapid transient lymphocytosis (Gleeson \& Bishop, 2005) and activation of specific signalling cascades within T cells (Siedlik et al., 2017). Given that activated $T$ cells are reported to express higher levels of VDR, particularly $\mathrm{CD}^{+}{ }^{+} \mathrm{T}$ cells, although $\mathrm{CD} 4^{+} \mathrm{T}$ cells also present relatively less but significantly high concentrations of VDR (Veldman et al., 2000), it could be hypothesized that exercise might act as a stimulus and activate and upregulate VDR expression by circulating $T$ cells. To our knowledge, the effects of exercise on T-cell VDR expression have not yet been investigated in a human population.

The aims of this study were threefold: (1) investigate the influence of age on T-cell VDR expression; (2) to assess the effect of a single bout of aerobic exercise on VDR expression in peripheral blood T cells; and (3) to investigate whether any impact of exercise on T-cell VDR expression is age dependent.

\section{2 | METHODS}

\subsection{Ethical approval}

Ethical approval of the study and its procedures was granted by the School of Applied Sciences Research Ethics and Governance Committee at Edinburgh Napier University. The study conformed to

\section{New Findings}

\section{- What is the central question of this study?} Does exercise affect vitamin D receptor expression in T lymphocytes in young, middle-aged and older adults?

- What is the main finding and its importance? Moderate-intensity cycling exercise increases vitamin $D$ receptor expression in vitamin Ddeficient men, independent of age, presenting a strategy to combat the prevalence of vitamin D deficiency.

the standards set by the Declaration of Helsinki, except for registration in a database. Written informed consent was obtained from all participants before their participation in the study.

\section{2 | Participants}

Thirty-five recreationally active men, with an average age of 44 (24-75) years, were included in the study (mean \pm SD: body mass $82.5 \pm 11.4 \mathrm{~kg}$, height $1.79 \pm 0.08 \mathrm{~m}$ and body mass index $25.7 \pm$ $3.1 \mathrm{~kg} / \mathrm{m}^{2}$ ). Participants were included if they were aged $18-45$ or 60-75 years, recreationally active according to the moderate-tovigorous physical activity (MVPA) guidelines provided by the American College of Sports Medicine (ACSM, 2013), defined as $>150$ min of moderate activity per week or 75 min of vigorous activity per week. Participants were excluded if they were using tanning beds, undergoing UV light therapy, were taking vitamin D supplements ( $>10 \mu \mathrm{g} / \mathrm{day}$ ), were currently unwell, had any cardiometabolic condition or were taking any medications that could affect the study measures (i.e., calcium or any drugs that could affect bone and mineral metabolism). If participants reported they had been on a holiday outside of the UK to a sunny destination, they were not enrolled into the study for a minimum of 2 months after the holiday, in order to avoid any influence of increased UV exposure on vitamin D status and metabolism (Weiss et al., 2016).

\subsection{Baseline anthropometric measurements}

Height and body mass were measured via a stadiometer and scales, respectively, and body mass index was calculated. Blood pressure (BP) was measured on the participant's non-dominant arm using a digital automatic BP monitor (Avant 2120, Nonin, Plymouth, Minnesota, USA) whilst the participant was in the supine position after a 5 min rest. The BP was measured three times and an average of the second and third readings for systolic and diastolic BP reported. 


\subsection{Quantification of peak oxygen uptake}

Peak oxygen uptake was determined using an incremental stepprotocol exercise test on an electromagnetically braked cycle ergometer (Corival CPET, Lode, Netherlands). After a 5 min warm-up at $80 \mathrm{~W}$, the intensity was increased by $30 \mathrm{~W}$ every 2 min until volitional exhaustion, immediately followed by a 5 min cool-down at $50 \mathrm{~W}$. Expired air and heart rate (HR) were measured continuously throughout the test via an online breath-by-breath gas analysis system (MetaLyzer 3B, Cortex, Germany) and a HR monitor (RS400, Polar Finland), respectively. The participant's peak oxygen uptake was identified as the highest oxygen uptake over a 30 s period during the test.

\section{5 | Experimental protocol}

Experimental procedures were completed in the months October-May to avoid the months that are associated with elevated UV exposure via the sun. The study was conducted at a latitude of $55.95^{\circ} \mathrm{N}$ (Edinburgh, Scotland, UK) with all participants included in the study residing in Edinburgh and the adjacent constituents.

Participants visited the laboratory on two occasions separated by $\geq 7$ days (the average span between visits was 9 days), to complete the two randomly ordered trials: control (CON) or an aerobic exercise protocol (AE). Randomization was performed by an online generator that creates random permutations of treatments for situations where participants $(n=36)$ were to receive all the 'treatments' (trials: CON and $A E$ ) in a random order (SEED number 22520). Participants were asked to abstain from consuming caffeine and alcohol and engaging in strenuous exercise in the $24 \mathrm{~h}$ before each trial. Participants were asked to maintain their normal diet and activity throughout the study.

For each visit, participants arrived at the laboratory between 07.30 and $08.30 \mathrm{~h}$ in a fasted state ( $10 \mathrm{~h}$ fast). Participants were seated on a laboratory bed, and a cannula (22-gauge BD VenflonTM Pro Safety I.V. Cannula, BD Biosciences, USA) was inserted into an antecubital vein of the forearm, with a baseline blood sample taken. Participants then either performed the $60 \mathrm{~min} A E$ protocol or remained seated for $60 \mathrm{~min}$ (CON trial), with HR monitored throughout (RS400, Polar). Blood samples were collected immediately after, 1 and $3 \mathrm{~h}$ postcessation of the $A E / C O N$ rest period, with the participant remaining seated and rested for the duration.

The AE protocol consisted of 60 min of continuous cycling on an electronically braked cycle ergometer (Corival CPET, Lode) at $55 \%$ of peak oxygen uptake, to correspond to an intensity below the estimated lactate threshold in non-elite men (Joyner \& Coyle, 2008). Participants were instructed to maintain a pedalling rate between 70 and 80 r.p.m.

\subsection{Measurement of $25(\mathrm{OH}) \mathrm{D}_{3}$ concentration}

Serum $25(\mathrm{OH}) \mathrm{D}_{3}$ concentration was determined by high-pressure liquid chromatography-tandem mass spectrometry (LC-MS/MS) in duplicate on a single day in one laboratory. Before injection into the mass spectrometer (Shimadzu Nexera X2 LC Binary Pump Model), $25(\mathrm{OH}) \mathrm{D}_{3}$ and deuterated internal standard (QMX Laboratories Ltd, UK) were extracted from serum samples via protein precipitation sample preparation. The internal standard (25-hydroxyvtamin $\mathrm{D}_{3}$ $\left[d_{3}\right]$ ) was added to serum samples at a concentration of $400 \mathrm{pg} / \mu \mathrm{l}$, then $300 \mu \mathrm{l}$ of acetonitrile was added to $100 \mu \mathrm{l}$ of spiked serum samples and vortexed. Solutions were incubated on ice for $30 \mathrm{~min}$ before centrifugation at $3000 \mathrm{~g}$ for $15 \mathrm{~min}$. The supernatant was removed via drying under a stream of nitrogen, and dried extracts were reconstituted in the mobile phase $(15 \% 5 \mathrm{mM}$ ammonium acetate + $0.1 \%$ acetic acid: $85 \%$ methanol) before injection (5 $\mu \mathrm{l}$ ) into an LC$\mathrm{MS} / \mathrm{MS}$ in the multiple reaction mode at a flow rate of $500 \mu \mathrm{l} / \mathrm{min}$. The retention time of the injected sample in the column was $2.01 \mathrm{~min}$. The intra-assay coefficients of variation (CV) for the LC-MS/MS assay was $3.04 \%$. At the lower concentration, the method demonstrated $\% \mathrm{CV}$ of 4.19 at a $25(\mathrm{OH}) \mathrm{D}_{3}$ concentration of $4.7 \mathrm{pg} / \mu \mathrm{l}$, with a high concentration of $986.7 \mathrm{pg} / \mu \mathrm{l}$ demonstrating a \%CV of 0.70 . Overall, the assay had an accuracy of $98.94 \%$.

Vitamin D status was categorized according to Institute of Medicine (IOM) definition (Ross et al., 2011): severe deficiency [serum $25(\mathrm{OH}) \mathrm{D}_{3}<12 \mathrm{ng} / \mathrm{ml}$ ], deficiency [serum $25(\mathrm{OH}) \mathrm{D}_{3}$ between 12 and $20 \mathrm{ng} / \mathrm{ml}$ ], insufficiency [serum $25(\mathrm{OH}) \mathrm{D}_{3}$ between 20 and $30 \mathrm{ng} / \mathrm{ml}$ ] or sufficiency [serum $25(\mathrm{OH}) \mathrm{D}_{3} \geq 30 \mathrm{ng} / \mathrm{ml}$.

\subsection{Measurement of VDR expression}

Flow cytometry analysis of $\mathrm{CD}^{+}, \mathrm{CD}^{+}$and $\mathrm{CD}^{+} \mathrm{T}$ cells to determine VDR expression was performed as previously reported (Bendix et al., 2015). Peripheral blood mononuclear cells were isolated from whole blood using density gradient media centrifugation (FicollPaque, Amersham Biosciences, Uppsala, Sweden). Non-permeabilized and permeabilized peripheral blood mononuclear cells were stained for VDR to analyse both cell surface and internalized VDR expression and analysed via a flow cytometer (BD FACSCelestaTM, San Jose, CA, USA).

Based on the cell count, a suspension of 500,000 cells was added to each tube and stained with $2 \mu \mathrm{l}$ of mouse anti-human CD3 antibody fluorescein isothiocyanate (FITC, Clone SK7; BD Biosciences), $2 \mu \mathrm{l}$ mouse anti-human CD4 antibody Brilliant Violet 786 (BV786, Clone SK3; BD Biosciences), $2 \mu \mathrm{l}$ mouse anti-human CD8 antibody phycoerythrin with the cyanide dye Cy5 (PE-Cy5; Clone RPAT8; BD Biosciences), $1 \mu \mathrm{l}$ rat anti-VDR monoclonal antibody (Clone 9A7; ThermoFisher Scientific, Massachusetts, USA) and $1 \mu \mathrm{l}$ of the secondary antibody to conjugate with the VDR antibody [goat anti-rat Ig, polyclonal, phycoerythrin (PE); BD Biosciences] was added to the cells and incubated at $4^{\circ} \mathrm{C}$ for $30 \mathrm{~min}$. After incubation, $1 \mathrm{ml}$ of PBS was added to all tubes, and the cells were washed at $250 \mathrm{~g}$ for $10 \mathrm{~min}$ at $20^{\circ} \mathrm{C}$. The cell pellet was resuspended in $500 \mu \mathrm{l}$ PBS via vortexing, and flow cytometry was performed within $1 \mathrm{~h}$, acquiring 50,000 events within the collect gate applied to the lymphocyte population. 

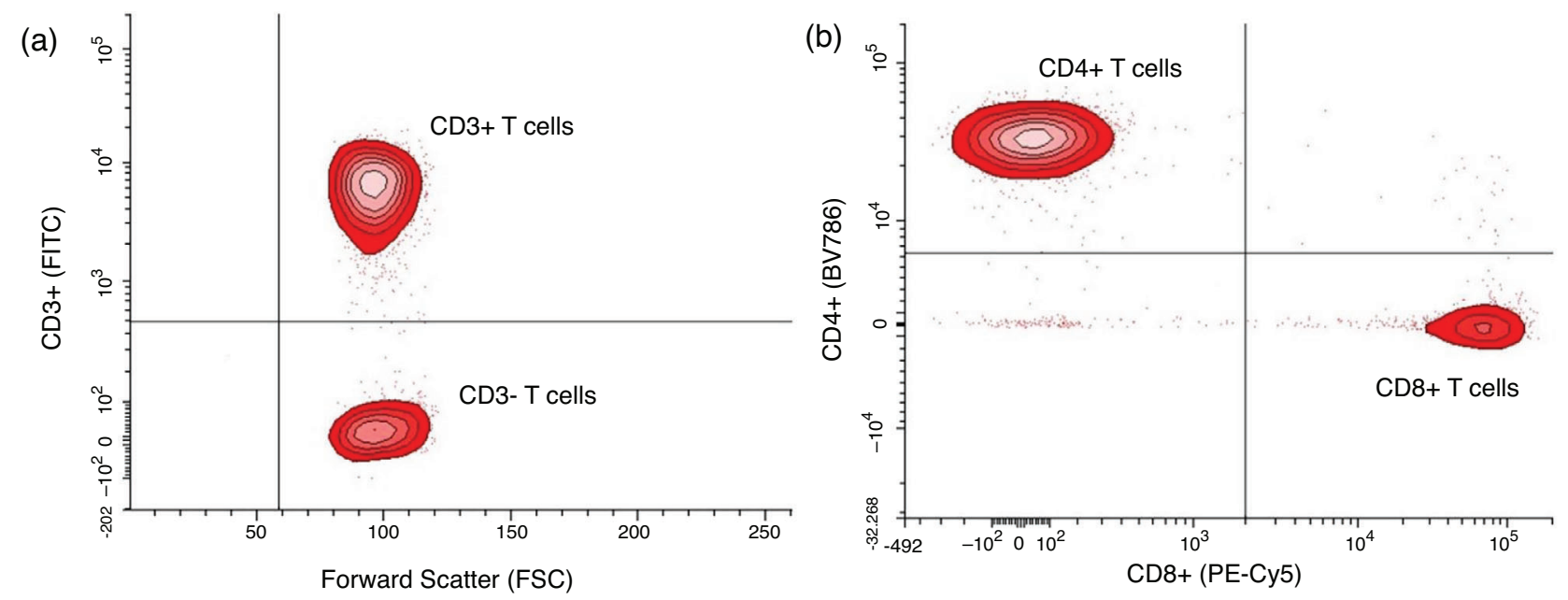

(c) 8

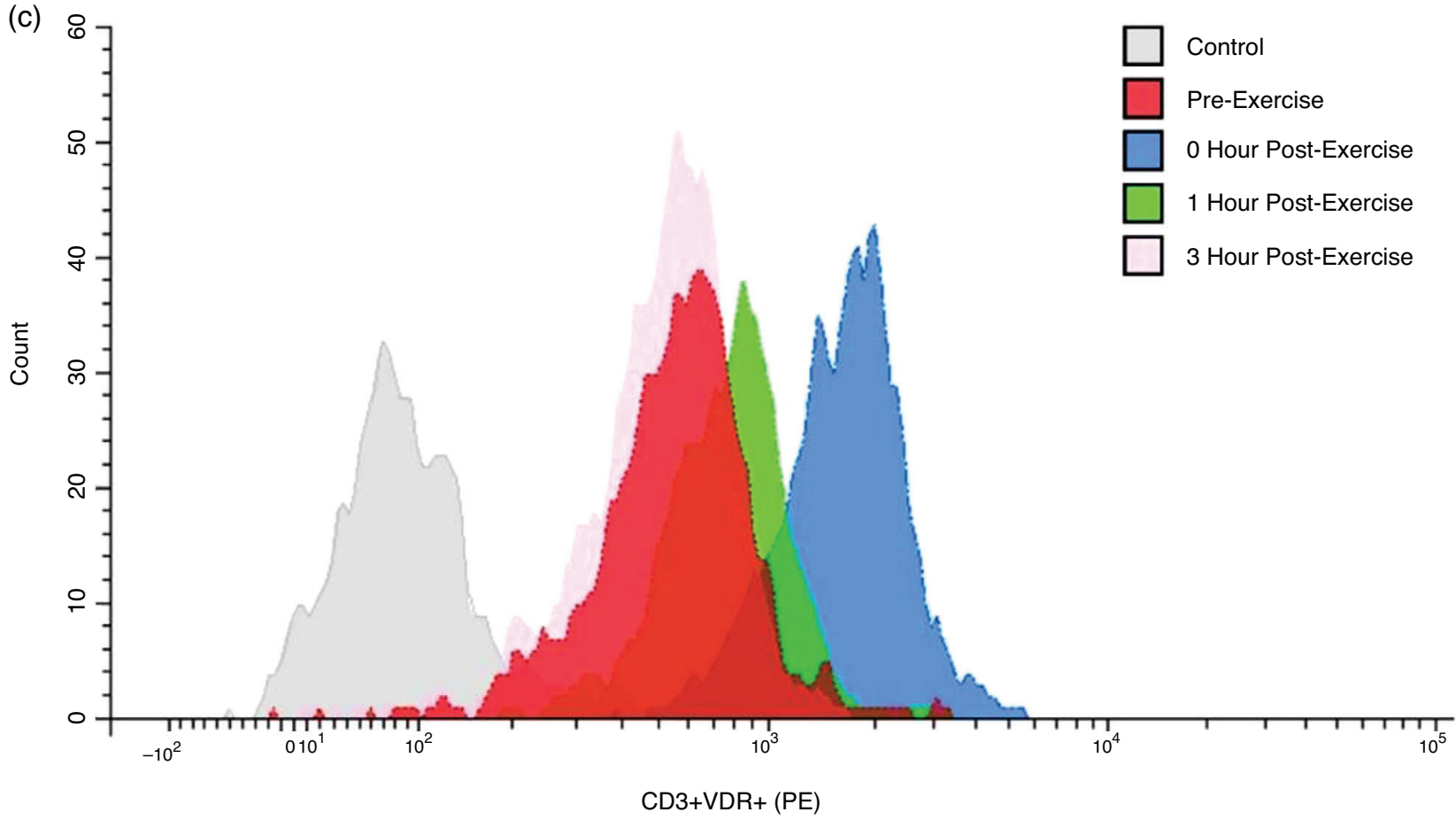

FIGURE 1 Flow cytometric quantification of $C D 3^{+} \mathrm{T}$ cells, $C D 3^{+} \mathrm{CD} 4^{+} \mathrm{T}$ cells and $\mathrm{CD} 3^{+} \mathrm{CD} 8^{+} \mathrm{T}$ cells. (a) $\mathrm{CD} 3^{+}$gating for identification of $\mathrm{T}$ cells. (b) Identification of $\mathrm{CD}^{+}$and $\mathrm{CD} 8^{+} \mathrm{T}$ cells. (c) Histogram of changes in $\mathrm{CD} 3^{+} \mathrm{VDR}^{+} \mathrm{T}$ cells in response to a bout of aerobic exercise

For the permeabilized method, after the initial incubation with the antibodies $250 \mu \mathrm{l}$ of Fixation/Permeabilisation Solution (BD Biosciences) was added and incubated for $20 \mathrm{~min}$ at $4^{\circ} \mathrm{C}$. One millilitre of Perm/Wash Buffer (10x; BD Biosciences) was added, and the cells were washed at $250 \mathrm{~g}$ for $10 \mathrm{~min}$ at $20^{\circ} \mathrm{C}$.

For the flow cytometric gating strategy, the lymphocyte population was gated (acquiring 50,000 events) using forward scatter and side scatter. $\mathrm{CD}^{+}$events were gated, followed by gating of $\mathrm{CD}^{+}$ and $\mathrm{CD}^{+}$populations, after which these cells were assessed for expression of VDR. Representative flow cytometry plots are provided in Figure 1.

The VDR expression is reported as the fold change, calculated from the VDR geometric mean (geomean). The absolute number of $\mathrm{T}$ cells was calculated and quantified using the lymphocyte concentration obtained via haematological analysis (Sysmex Automated Haematology Analyser, XS 1000i, Sysmex, Japan). All haematological data were adjusted to account for any changes in plasma volume from baseline (Dill \& Costill, 1974).

\subsection{Statistical analysis}

All statistical tests were performed using SPSS v.23.0 statistical software (IBM Analytics, New York, USA). The physical characteristics, performance measures and baseline vitamin D status were compared between age groups by one-way ANOVA. To determine the effect of 
exercise on the number of cells and VDR expression, a three-factorial repeated-measures ANOVA was used, with age as the betweensubjects factor and time (pre, 0, 1 and $3 \mathrm{~h}$ ) and exercise condition (CON and $A E$ ) as within-subject factors. The normality of the residuals in the model was tested using the Shapiro-Wilk test and inspected visually, with all residuals in the model normally distributed. The repeatedmeasures ANOVA was time (pre, 0, 1 and $3 \mathrm{~h}$ ), with the model applied to each cell type: $\mathrm{CD}^{+}, \mathrm{CD}^{+}$and $\mathrm{CD}^{+} \mathrm{T}$ cells. Where significant differences were detected, Bonferroni post hoc tests were performed to identify the location of the effect.

The Pearson correlation coefficient was used to analyse the correlations between the change in the number of cells and the change in VDR expression. Significance was accepted at $P<0.05$. Values shown are the mean \pm SD unless otherwise stated.

\section{3 | RESULTS}

\section{1 | Participant characteristics}

Thirty-five participants completed all trials. The participant characteristics and baseline $25(\mathrm{OH}) \mathrm{D}_{3}$ concentration according to age group are presented in Table 1 . There were no significant differences between age groups for baseline characteristics except for diastolic BP $[F(2,32)=7.447, P=0.002]$, whereby subjects aged 31-45 years had a lower diastolic BP compared with subjects aged 60-75 years $(P=0.001)$.

\subsection{Circulating vitamin D and T-cell VDR expression}

As shown in Figure $2 \mathrm{a}$, the serum $25(\mathrm{OH}) \mathrm{D}_{3}$ concentration (in nanograms per millilitre or nanomoles per litre) did not differ between age groups $[F(2,34)=0.258, P=0.774]$; collectively, participants were all defined as vitamin $D$ deficient $(15.7 \pm 6.4 \mathrm{ng} / \mathrm{ml})$. Age was found to influence baseline VDR expression in circulating $C D 3^{+}$ $[F(2,34)=4.763, P=0.015], C D^{+}[F(2,34)=4.800, P=0.014]$ and $\mathrm{CD}^{+}[F(2,34)=4.852, P=0.014] \mathrm{T}$ cells, as shown in Figure $2 \mathrm{~b}$. Older adults displayed lower levels of the receptor compared with their young counterparts $\left(C D 3^{+}, P=0.013 ; \mathrm{CD}^{+}, P=0.014 ; \mathrm{CD}^{+}\right.$, $P=0.012)$. There was no association between baseline $25(\mathrm{OH}) \mathrm{D}_{3}$ concentration and $\mathrm{CD}^{+}{ }^{+}$T-cell VDR expression $(n=35, r=0.046$, $P=0.793)$

\subsection{Physiological responses to the trials}

There was a main effect of the trial on the mean HR [CON, $58 \pm$ 7 beats/min; AE, $136 \pm 14$ beats $/ \mathrm{min} ; F(2,60)=463.090, P<0.001]$, with a trial-by-age group interaction $[F(4,60)=4.169, P=0.005]$, whereby mean HR was higher in group aged 18-30 compared with 6075 years $(P=0.017)$ for AE. Mean HR remained unchanged during the $1 \mathrm{~h}$ rest period in the $\mathrm{CON}$ trial.

\section{4 | T-Cell VDR expression in response to aerobic exercise}

The T-cell VDR expression was expressed as the fold change, in order to allow for comparison between trials and age groups relative to the change, rather than absolute values, owing to differences in baseline VDR expression between age groups (Figure $2 b$ ).

As shown in Figure 3, there was a significant main effect of time on VDR expression in $\mathrm{CD}^{+}[F(3,90)=12.634, P<0.001]$, $\mathrm{CD}^{+}$ $[F(3,90)=8.230, P<0.001]$ and $\mathrm{CD}^{+} \mathrm{T}$ cells $[F(3,90)=7.456$, $P<0.001$ ]. There was an interaction between time and the trial (CON or $\mathrm{AE}$ ) for $\mathrm{CD}^{+}[F(3,90)=10.406, P<0.001], \mathrm{CD}^{+}[F(3,90)=5.475$, $P=0.001]$ and $\mathrm{CD}^{+} \mathrm{T}$ cells $[F(3,90)=4.456, P=0.006]$. Post hoc analysis showed that $\mathrm{CD}^{+}, \mathrm{CD}^{+}$and $\mathrm{CD}^{+}{ }^{+} \mathrm{T}$-cell VDR expression

TAB LE 1 Participants physical and performance characteristics $(n=35)$

\begin{tabular}{|c|c|c|c|c|c|c|c|}
\hline Characteristic & All $(n=35)$ & $\begin{array}{l}18-30 \text { years } \\
(n=12)\end{array}$ & $\begin{array}{l}31-45 \text { years } \\
(n=11)\end{array}$ & $\begin{array}{l}60-75 \text { years } \\
(n=12)\end{array}$ & d.f. & $F$ & $P$-value \\
\hline Age (years) & $44(24-75)$ & $27(24-30)$ & $38(31-45)^{*}$ & $67(60-75)^{*} \dagger$ & 2,32 & 284.735 & $<0.001$ \\
\hline Body mass (kg) & $82.5 \pm 11.4$ & $83.8 \pm 13.0$ & $80.9 \pm 11.0$ & $82.7 \pm 10.8$ & 2,32 & 0.180 & 0.836 \\
\hline Body mass index $\left(\mathrm{kg} / \mathrm{m}^{2}\right)$ & $25.7 \pm 3.1$ & $25.6 \pm 3.9$ & $25.8 \pm 2.5$ & $25.9 \pm 2.9$ & 2,32 & 0.030 & 0.970 \\
\hline Systolic blood pressure $(\mathrm{mmHg})$ & $122 \pm 11$ & $124 \pm 10$ & $119 \pm 12$ & $122 \pm 11$ & 2,32 & 0.739 & 0.486 \\
\hline Diastolic blood pressure (mmHg) & $73 \pm 8$ & $73 \pm 7$ & $67 \pm 5$ & $78 \pm 8 \dagger$ & 2,32 & 7.447 & 0.002 \\
\hline Maximal heart rate (beats/min) & $175 \pm 19$ & $189 \pm 10$ & $178 \pm 8^{*}$ & $160 \pm 20^{*} \dagger$ & 2,33 & 13.041 & $<0.001$ \\
\hline Relative peak oxygen uptake $\left(\mathrm{ml} / \mathrm{kg}^{-1} / \mathrm{min}\right)$ & $38.0 \pm 8.2$ & $42.1 \pm 7.9$ & $41.4 \pm 7.2^{*}$ & $30.9 \pm 3.8^{*} \dagger$ & 2,34 & 10.894 & $<0.001$ \\
\hline Absolute peak power $(\mathrm{W})$ & $261 \pm 60$ & $282 \pm 49$ & $293 \pm 61^{*}$ & $212 \pm 34^{*} \dagger$ & 2,34 & 9.335 & 0.001 \\
\hline
\end{tabular}

All data are presented as the mean \pm SD, except for age, which is presented as the mean (range). "Significant difference from 18-30 years $(P<0.05)$. $\dagger$ Significant difference from $31-45$ years $(P<0.05)$. 


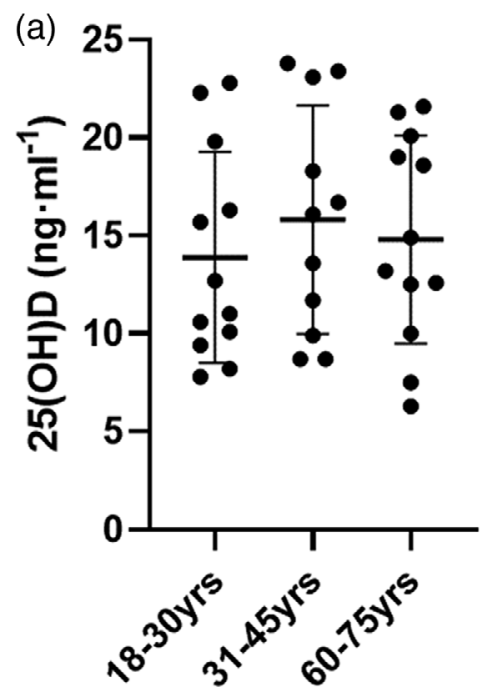

(b)

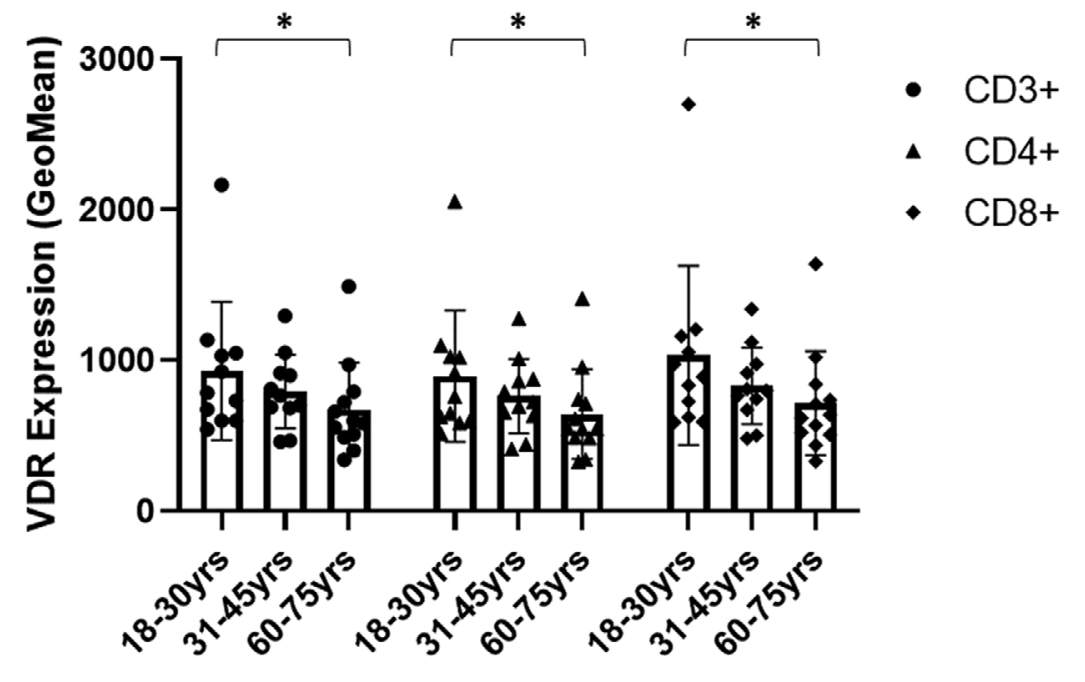

FIGURE 2 Baseline serum 25(OH) $\mathrm{D}_{3}$ concentration (a), and baseline VDR expression in T-cell subsets (circles, CD3 ${ }^{+}$; triangles, CD4+; diamonds, $C D 8^{+}$) expressed as the geomean (b), for subjects aged 18-30, 31-45 and 60-75 years. Data are presented as the mean \pm SD. *Significant difference between $60-75$ and $18-30$ years $(P<0.05)$

\section{Control}
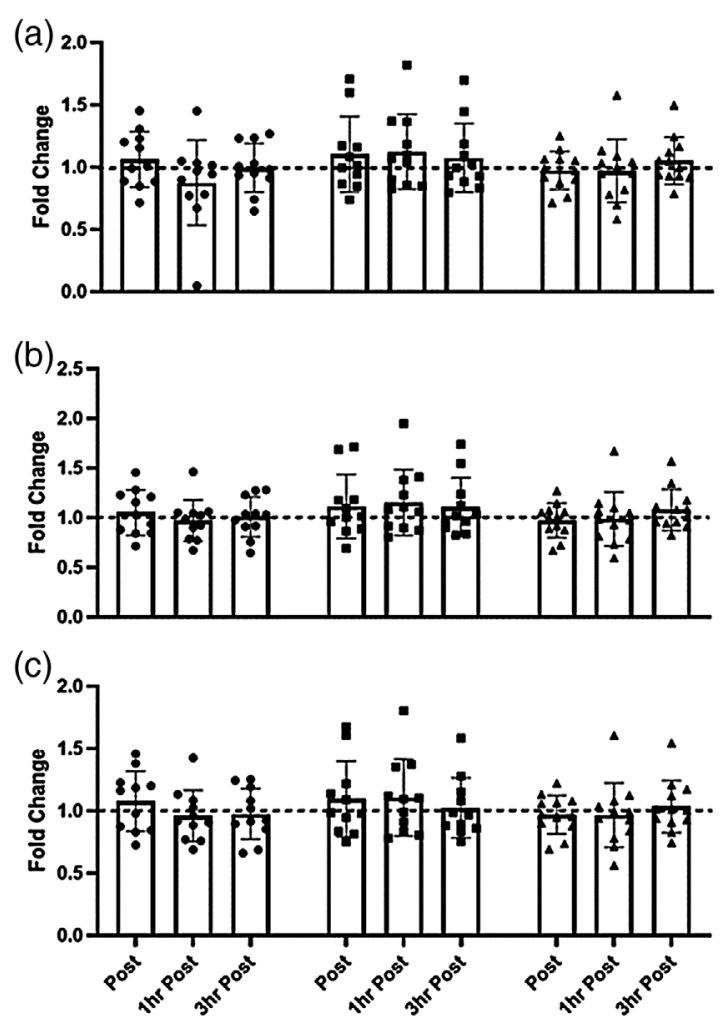

\section{Aerobic Exercise}

(d)

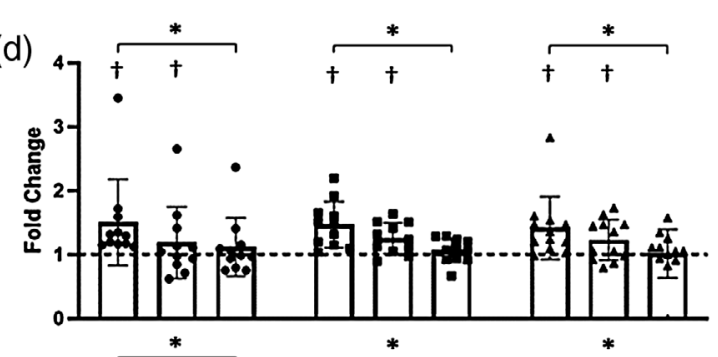

(e)

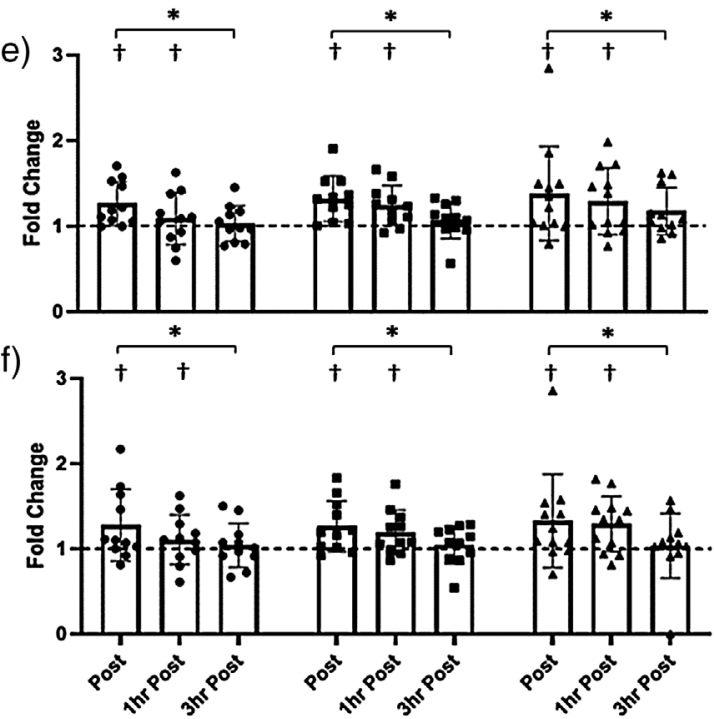

FIGURE 3 Changes in VDR expression in $\mathrm{CD}^{+}, \mathrm{CD}^{+}$and $\mathrm{CD} 8^{+} \mathrm{T}$ cells during the control trial ( $\mathrm{a}$, $\mathrm{b}$ and $\mathrm{c}$, respectively) and in response to a single bout of aerobic exercise ( $d$, e and f, respectively). The dotted line denotes baseline VDR expression. Data are expressed as the fold change and shown for each age group: 18-30 (circles), 31-45 (squares) and 60-75 years (triangles). Data are presented as the mean \pm SD. ${ }^{*}$ Significant main effect of time $(P \leq 0.05)$. ${ }^{\dagger}$ Significant fold change from one $(P \leq 0.05)$ 
$-\pi \cdot 31-45 \mathrm{yrs}$

(b)

(a)

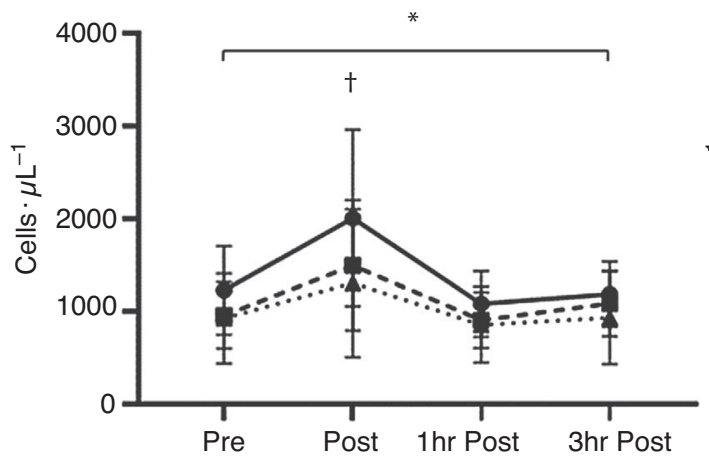

(c)

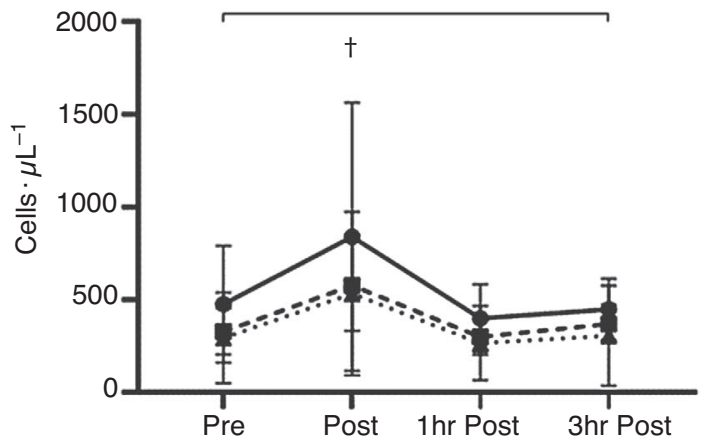

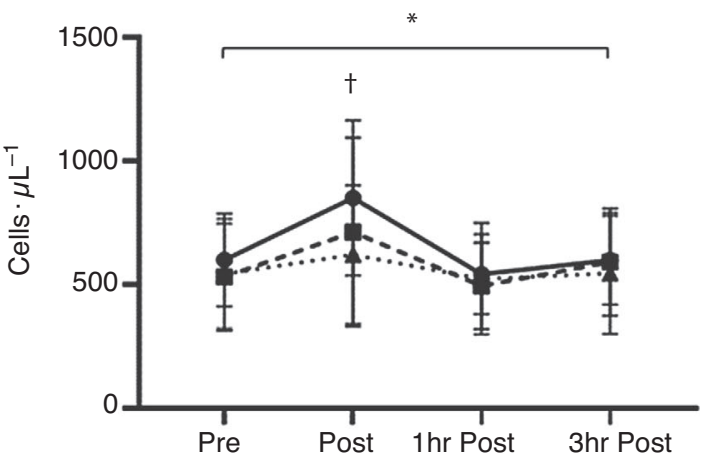

FIGURE 4 Changes in the number of $\mathrm{CD}^{+}$(a), $C D 4^{+}$(b) and $C D 8^{+}$(c) T cells in response to a single bout of aerobic exercise for subjects aged 18-30 (circles), 31-45 (squares) and 60-75 years (triangles). Data are presented as the mean \pm SD. *Significant main effect of the trial $(P \leq 0.05)$.

†ignificant difference from Pre $(P \leq 0.05)$

was significantly greater immediately after exercise $(P<0.001$, $P=0.001$ and $P=0.005$, respectively); however, $\mathrm{CD}^{+}$and $\mathrm{CD}^{+}$ expression declined at $1 \mathrm{~h}$ postexercise, whereas expression in $\mathrm{CD}^{+}$ T cells remained elevated $(P=0.015)$. There was no significant interaction with age during either of the trials $(P>0.05)$.

\subsection{Relationship between change in number of $T$ cells and VDR expression}

In order to determine whether the change in VDR expression observed was independent of the exercise-induced transient rise and decline in the number of cells in the circulation (Gleeson \& Bishop, 2005), a correlation analysis was conducted between the change in the number of cells (Figure 4) and the change in VDR expression (geomean) from each time point to the next (Table 2). There was no relationship between the number of cells in the circulation and the expression of the receptor in $\mathrm{CD}^{+}$and $\mathrm{CD}^{+}{ }^{+} \mathrm{T}$ cells during the $\mathrm{AE}$ trial. There was a correlation for $\mathrm{CD}^{+} \mathrm{T}$ cells from 1 to $3 \mathrm{~h}$ postexercise $(P=0.043)$, whereby there was an increase in the number of cells but a decrease in VDR expression.

\section{DISCUSSION}

This is the first study to show that older adults display lower levels of VDR in T-cells, and a single bout of aerobic exercise was successful in stimulating increases in T-cell VDR expression. Despite there being lower levels of VDR expression in T-cells of older compared with younger adults, there was no age-induced difference in the responsiveness of VDR expression to the exercise bout.

The data show that VDR expression increases in line with T-cell elevations in circulation, which might be attributable to either selective ingress of T-cells with high levels of VDR expression or upregulation of VDR protein expression in T cells. However, after a simple analysis, the data suggest that there is no link between the change in the number of cells and expression of the receptor. Therefore, it could be hypothesized that the cells themselves upregulate expression of VDR. This does not rule out the potential that the observed increases in VDR signal are a result of selective mobilization of T-cells with high expression of the receptor in response to acute cardiovascular system stress (Bosch et al., 2003).

In the present study, the data show that baseline serum $25(\mathrm{OH}) \mathrm{D}_{3}$ concentration is not related to VDR expression in circulating T-cells. 
TAB LE 2 Correlations between the change $(\Delta)$ in the number of cells and the change in VDR expression in response to a single bout of aerobic exercise $(n=35)$

\begin{tabular}{|c|c|c|c|c|c|}
\hline Cell type & Time points & $\Delta$ Number of cells & $\begin{array}{l}\triangle \text { VDR expression } \\
\text { (Geomean) }\end{array}$ & Correlation & $P$-value \\
\hline \multirow[t]{2}{*}{$\mathrm{CD}^{+}$} & Pre-0 h & $545 \pm 629$ & $300 \pm 332$ & -0.145 & 0.406 \\
\hline & $1 \mathrm{~h}-3 \mathrm{~h}$ & $113 \pm 236$ & $-113 \pm 240$ & 0.331 & 0.052 \\
\hline \multirow[t]{2}{*}{$\mathrm{CD}^{+}$} & Pre-Oh & $158 \pm 308$ & $229 \pm 284$ & 0.558 & 0.558 \\
\hline & $1 \mathrm{~h}-3 \mathrm{~h}$ & $53 \pm 128$ & $-104 \pm 230$ & 0.114 & 0.515 \\
\hline \multirow[t]{3}{*}{$\mathrm{CD}^{+}$} & Pre-0h & $267 \pm 322$ & $229 \pm 358$ & -0.212 & 0.221 \\
\hline & $0 h-1 h$ & $-309 \pm 393$ & $-74 \pm 311$ & -0.025 & 0.884 \\
\hline & $1 \mathrm{~h}-3 \mathrm{~h}$ & $49 \pm 107$ & $-135 \pm 273$ & 0.344 & 0.043 \\
\hline
\end{tabular}

All data are presented as the mean \pm SD.

Our results are in agreement with previous findings of no relationship between serum $25(\mathrm{OH}) \mathrm{D}_{3}$ concentrations and mucosal VDR levels in the intestine (Kinyamu et al., 1997) or VDR expression in skeletal muscle tissue of young or elderly women (Bischoff-Ferrari et al., 2004). The lack of association might be influenced by the relatively low serum $25(\mathrm{OH}) \mathrm{D}_{3}$ concentrations observed in the majority of the participants: mean of $15.7 \pm 6.4 \mathrm{ng} / \mathrm{ml}$, classified as a vitamin D-deficient status (Holick \& Chen, 2008). Owing to the northern latitude of the UK, if participants do not consume regular vitamin $D$ supplements they are likely to be defined as vitamin $D$ insufficient. This was also included in the eligibility criteria for the present study.

The data from the present investigation show that baseline VDR expression in T-cells was significantly lower in older men (6075 years) compared with younger men (18-30 years). This finding is in agreement with previous reports from Bischoff-Ferrari et al. (2004), who observed older age to be associated with decreased VDR protein expression. However, this contrasts with Coleman et al. (2016), who reported no association between the expression and function of VDR in immune cells with age. The disagreement might be attributable to the different cell types (skeletal muscle cells compared with circulating $\mathrm{T}$ cells) and/or the population investigated. Although human males were included in the studies, the study by Coleman et al. (2016) included adults $\geq 50$ years of age, whereas in the present study a young age group was compared with an older adult population. It has previously been reported that older adults display greater numbers of senescent T-cells than younger counterparts (Simpson et al., 2007), which is associated with altered receptor expression (Mo et al., 2003). Therefore, the number of senescent cells present might influence the downregulation in VDR expression observed with age.

Previous studies have demonstrated that a single bout of exercise can acutely increase the serum $25(\mathrm{OH}) \mathrm{D}_{3}$ concentration in humans (Sun et al., 2017) and intramuscular VDR expression in male rats (Makanae et al., 2015). In the study by Makanae et al. (2015), resistance-based exercise appeared to increase VDR expression, whereas the present study is the first to demonstrate that acute aerobic exercise can upregulate VDR expression in peripheral blood
T-cells in a human male population. Interestingly, Sun et al. (2017) observed an exercise-induced increase in systemic vitamin D levels, which could influence the availability of downstream metabolites, hence expression of VDR in a demand-and-supply response. However, this requires mechanistic investigations to determine the full impact of exercise on vitamin D metabolism.

In the present study, we observed an initial rise in lymphocyte count in response to an acute bout of aerobic exercise, followed by an immediate decline postexercise in the recovery phase, which is a well-established and reported response (Nieman et al., 1991; Simpson et al., 2007). The increase in peripheral blood lymphocytes with acute exercise is attributed to increases in cardiac output and concomitant haemodynamic shear forces that demarginate the peripheral lymphocyte cell pools (Shephard, 2003) and/or cell mobilization and redistribution from tissues into the circulation via $\beta_{2}$-adrenergic mechanisms (Murray et al., 1992). Interestingly, in the present study we found no significant relationship between the change in the number of cells in response to exercise and the increase in VDR expression. This could suggest that the upregulation in VDR expression might not be dependent on endothelial detachment and subsequent recirculation of cells that express high levels of VDR, but an increase in the VDR protein within the cells. However, this does not rule out the possibility that the observed increases in VDR signal via flow cytometry are a result of selective mobilization of T-cells with high expression of VDR.

The VDR has a relatively short half-life of $1.7 \mathrm{~h}$ in untreated T-cells and $2.9 \mathrm{~h}$ in T-cells treated with $25(\mathrm{OH}) \mathrm{D}_{3}$ (Kongsbak et al., 2014). The VDR is degraded in the cytosol and nucleus, with $1,25(\mathrm{OH})_{2} \mathrm{D}_{3}$ upregulating the VDR by increasing VDR mRNA expression and/or stabilizing the VDR at the protein level by protecting it from proteasomal degradation (Kongsbak et al., 2014). The acute increase in VDR protein expression observed in the present study in response to aerobic exercise might be short term owing to the short half-life of the VDR. If the exercise bout increases intracellular VDR expression with an immediate decline during the hour after the exercise, this might suggest that the VDR begins to degrade upon cessation of the physical demand. However, exploration of this potential mechanism is required. 
Finally, our study has some important limitations. The flow cytometric analysis assay could have incorporated T-cell phenotyping (i.e., markers of memory, naïve and senescent cells), in order to provide some insight into whether the increase in VDR was attributable to exercise or specific ingress of VDR-expressing cells. This would have been valuable, given the aim of identifying the role of age in this response to exercise. In addition, there was no control over diet during participant involvement in the study, although the eligibility criteria did ensure that participants did not consume vitamin D supplements and thus were likely to be insufficient at baseline. Moreover, participants were asked to maintain their habitual activity and diet. Further to this, only men were included in the study owing to the impact that sex-specific differences have on the hormone profile and thus might have on vitamin $D$ metabolism. This presents an avenue for future investigations.

\section{1 | Conclusion}

In summary, we have demonstrated, for the first time, that older adults display lower levels of VDR expression in T cells and that a single bout of aerobic exercise acutely increases T-cell VDR expression in vitamin D-deficient men independently of age. This was observed immediately upon cessation of the exercise bout, with a subsequent reduction in VDR expression, indicating that the response is transient. These novel results suggest that exercise could be an efficient way to increase systemic cellular VDR expression in a human population, albeit only acutely. A decline in VDR expression in $\mathrm{T}$ cells with advancing age presents an issue with regard to this cell development and thus autoimmunity. Therefore, enhancing the VDR expression in $T$ cells might have a therapeutic effect, especially for older adults who appear to be at risk of VDR deficiency.

\section{ACKNOWLEDGEMENTS}

The authors thank the participants for their time and effort and thank and acknowledge Mr Neil Guthrie, Mr Mindaugas Jurevicius, Ms Marina Mocogni and Mr Russell Wilson for their technical assistance. This study was funded by Edinburgh Napier University.

\section{AUTHOR CONTRIBUTIONS}

Experiments were performed in the Sport and Exercise Science Laboratory at Edinburgh Napier University. Conception and design of the work and analysis and interpretation of data: H.L., M.L., G.F.J. and M.R. Acquisition of data: H.L. and G.D. Drafting of the work: H.L. Critical revision of the work: all authors. All authors approved the final version of manuscript and agree to be accountable for all aspects of the work in ensuring that questions related to the accuracy or integrity of any part of the work are appropriately investigated and resolved. All persons designated as authors qualify for authorship, and all those who qualify for authorship are listed.

\section{COMPETING INTERESTS}

None declared.

\section{DATA AVAILABILITY STATEMENT}

All data generated or analysed during this study are included in this published article or in the data repositories listed in the References.

\section{ORCID}

Hannah Lithgow (D) https://orcid.org/0000-0003-3882-9773

Mark Ross (D) https://orcid.org/0000-0002-0204-3915

\section{REFERENCES}

ACSM. (2013). ACSM's Guidelines for exercise testing and prescription (9th edn.). Lippincott Williams and Wilkins.

Aly, Y. E., Abdou, A. S., Rashad, M. M., \& Nassef, M. M. (2016). Effect of exercise on serum vitamin $D$ and tissue vitamin $D$ receptors in experimentally induced type 2 diabetes mellitus. Journal of Advanced Research, 7, 671-679. https://doi.org/10.1016/j.jare.2016.07 .001

Baeke, F., Korf, H., Overbergh, L., van Etten, E., Verstuyf, A., Gysemans, C., \& Mathieu, C. (2010). Human T lymphocytes are direct targets of 1,25-dihydroxyvitamin $D_{3}$ in the immune system. Journal of Steroid Biochemistry and Molecular Biology, 121, 221-227. https://doi.org/10. 1016/j.jsbmb.2010.03.037

Bass, J. J., Nakhuda, A., Deane, C. S., Brook, M. S., Wilkinson, D. J., Phillips, B. E., Philp, A., Tarum, J., Kadi, F., Andersen, D., Muñoz Garcia, A., Smith, K., Gallagher, I. J., Szewczyk, N. J., Cleasby, M. E., \& Atherton, P. J. (2020). Overexpression of the vitamin D receptor (VDR) induces skeletal muscle hypertrophy. Molecular Metabolism, 42, 101059. https://doi.org/ 10.1016/j.molmet.2020.101059

Bendix, M., Dige, A., Deleuran, B., Dahlerup, J. F., Jørgensen, S. P., Bartels, L. E., Husted, L. B., Harsløf, T., Langdahl, B., \& Agnholt, J. (2015). Flow cytometry detection of vitamin $\mathrm{D}$ receptor changes during vitamin $\mathrm{D}$ treatment in Crohn's disease. Clinical and Experimental Immunology, 181, 19-28. https://doi.org/10.1111/cei.12613

Bischoff-Ferrari, H. A., Borchers, M., Gudat, F., Dürmüller, U., Stähelin, H. B., \& Dick, W. (2004). Vitamin D receptor expression in human muscle tissue decreases with age. Journal of Bone and Mineral Research, 19, 265-269. https://doi.org/10.1359/jbmr.2004.19.2.265

Bosch, J. A., Berntson, G. G., Cacioppo, J. T., Dhabhar, F. S., \& Marucha, P. T. (2003). Acute stress evokes selective mobilization of T cells that differ in chemokine receptor expression: A potential pathway linking immunologic reactivity to cardiovascular disease. Brain, Behavior, and Immunity, 17, 251-259. https://doi.org/10.1016/S0889-1591(03)00054-0

Coleman, L. A., Mishina, M., Thompson, M., Spencer, S. M., Reber, A. J., Davis, W. G., Cheng, P. Y., Belongia, E. A., Talbot, H. K., Sundaram, M. E., Griffin, M. R., Shay, D. K., \& Sambhara, S. (2016). Age, serum 25hydroxyvitamin D and vitamin D receptor (VDR) expression and function in peripheral blood mononuclear cells. Oncotarget, 7, 35512-35521. https://doi.org/10.18632/oncotarget.9398

Dill, D. B., \& Costill, D. L. (1974). Calculation of percentage changes in volumes of blood, plasma, and red cells in dehydration. Journal of Applied Physiology, 37, 247-248. https://doi.org/10.1152/jappl.1974.37.2.247

Gleeson, M., \& Bishop, N. C. (2005). The T cell and NK cell immune response to exercise. Annals of Transplantation, 10, 43-48.

Haussler, M. R., Whitfield, G. K., Haussler, C. A., Hsieh, J. C., Thompson, P. D., Selznick, S. H., Dominguez, C. E., \& Jurutka, P. W. (1998). The nuclear vitamin $D$ receptor: Biological and molecular regulatory properties revealed. Journal of Bone and Mineral Research, 13, 325-349. https://doi. org/10.1359/jbmr.1998.13.3.325

Hewison, M. (2012). Vitamin D and immune function: An overview. The Proceedings of the Nutrition Society, 71, 50-61. https://doi.org/10.1017/ S0029665111001650

Holick, M. F., \& Chen, T. C. (2008). Vitamin D deficiency: A worldwide problem with health consequences [Review]. American Journal of Clinical Nutrition, 87, 1080S-1086S. https://doi.org/10.1093/ajcn/87.4.1080S 
Joyner, M. J., \& Coyle, E. F. (2008). Endurance exercise performance: The physiology of champions. The Journal of Physiology, 586, 35-44. https: //doi.org/10.1113/jphysiol.2007.143834

Kinyamu, H. K., Gallagher, J. C., Prahl, J. M., DeLuca, H. F., Petranick, K. M., \& Lanspa, S. J. (1997). Association between intestinal vitamin $D$ receptor, calcium absorption, and serum 1,25 dihydroxyvitamin D in normal young and elderly women. Journal of Bone and Mineral Research, 12, 922-928. https://doi.org/10.1359/jbmr.1997.12.6.922

Kongsbak, M., Levring, T. B., Geisler, C., \& von Essen, M. R. (2013). The vitamin $\mathrm{D}$ receptor and T cell function. Frontiers in Immunology, 4, 148. https://doi.org/10.3389/fimmu.2013.00148

Kongsbak, M., von Essen, M. R., Boding, L., Levring, T. B., Schjerling, P., Lauritsen, J. P., Woetmann, A., Ødum, N., Bonefeld, C. M., \& Geisler, C. (2014). Vitamin D up-regulates the vitamin D receptor by protecting it from proteasomal degradation in human $\mathrm{CD}_{4}^{+} \mathrm{T}$ cells. PLoS One, 9, e96695. https://doi.org/10.1371/journal.pone.0096695

Makanae, Y., Ogasawara, R., Sato, K., Takamura, Y., Matsutani, K., Kido, K., Shiozawa, N., Nakazato, K., \& Fujita, S. (2015). Acute bout of resistance exercise increases vitamin $\mathrm{D}$ receptor protein expression in rat skeletal muscle. Experimental Physiology, 100, 1168-1176. https://doi.org/10. 1113/EP085207

Mo, R., Chen, J., Han, Y., Bueno-Cannizares, C., Misek, D. E., Lescure, P. A., Hanash, S., \& Yung, R. L. (2003). T cell chemokine receptor expression in aging. The Journal of Immunology, 170, 895-904. https://doi.org/10. 4049/jimmunol.170.2.895

Murray, D. R., Irwin, M., Rearden, C. A., Ziegler, M., Motulsky, H., \& Maisel, A. S. (1992). Sympathetic and immune interactions during dynamic exercise. Mediation via a $\beta_{2}$-adrenergic-dependent mechanism. Circulation, 86, 203-213. https://doi.org/10.1161/01.CIR.86.1.203

Nieman, D. C., Nehlsen-Cannarella, S. L., Donohue, K. M., Chritton, D. B., Haddock, B. L., Stout, R. W., \& Lee, J. W. (1991). The effects of acute moderate exercise on leukocyte and lymphocyte subpopulations. Medicine and Science in Sports and Exercise, 23, 578-585. https://doi.org/ 10.1249/00005768-199105000-00010

Provvedini, D. M., Tsoukas, C. D., Deftos, L. J., \& Manolagas, S. C. (1983). 1,25-Dihydroxyvitamin $D_{3}$ receptors in human leukocytes. Science, 221(4616), 1181-1183. https://doi.org/10.1126/science.6310748

Ross, A. C., Manson, J. E., Abrams, S. A., Aloia, J. F., Brannon, P. M., Clinton, S. K., Durazo-Arvizu, R. A., Gallagher, J. C., Gallo, R. L., Jones, G., Kovacs, C. S., Mayne, S. T., Rosen, C. J., \& Shapses, S. A. (2011). The 2011 report on dietary reference intakes for calcium and vitamin $D$ from the Institute of Medicine: What clinicians need to know. Journal of Clinical Endocrinology and Metabolism, 96, 53-58. https://doi.org/10.1210/jc.2010-2704
Shephard, R. J. (2003). Adhesion molecules, catecholamines and leucocyte redistribution during and following exercise. Sports Medicine (Auckland, N.Z.), 33, 261-284. https://doi.org/10.2165/ 00007256-200333040-00002

Siedlik, J. A., Deckert, J. A., Benedict, S. H., Bhatta, A., Dunbar, A. J., Vardiman, J.P., \& Gallagher, P. M. (2017). T cell activation and proliferation following acute exercise in human subjects is altered by storage conditions and mitogen selection. Journal of Immunological Methods, 446, 7-14. https: //doi.org/10.1016/j.jim.2017.03.017

Simpson, R. J., Florida-James, G. D., Cosgrove, C., Whyte, G. P., Macrae, S., Pircher, H., \& Guy, K. (2007). High-intensity exercise elicits the mobilization of senescent $T$ lymphocytes into the peripheral blood compartment in human subjects. Journal of Applied Physiology, 103, 396401. https://doi.org/10.1152/japplphysiol.00007.2007

Sun, X., Cao, Z. B., Taniguchi, H., Tanisawa, K., \& Higuchi, M. (2017). Effect of an acute bout of endurance exercise on serum 25(OH)D concentrations in young adults. Journal of Clinical Endocrinology and Metabolism, 102, 3937-3944. https://doi.org/10.1210/jc.2017-00146

Veldman, C. M., Cantorna, M. T., \& DeLuca, H. F. (2000). Expression of 1,25-dihydroxyvitamin $D_{3}$ receptor in the immune system. Archives of Biochemistry and Biophysics, 374, 334-338. https://doi.org/10.1006/abbi. 1999.1605

Wang, Y., Zhu, J., \& DeLuca, H. F. (2012). Where is the vitamin D receptor? Archives of Biochemistry and Biophysics, 523, 123-133. https://doi.org/10. 1016/j.abb.2012.04.001

Weiss, E., Zgaga, L., Read, S., Wild, S., Dunlop, M. G., Campbell, H., McQuillan, R., \& Wilson, J. F. (2016). Farming, foreign holidays, and vitamin D in Orkney. PLoS One, 11, e0155633. https://doi.org/10.1371/journal.pone. 0155633

Yamshchikov, A. V., Desai, N. S., Blumberg, H. M., Ziegler, T. R., \& Tangpricha, V. (2009). Vitamin D for treatment and prevention of infectious diseases: A systematic review of randomized controlled trials. Endocrine Practice, 15, 438-449. https://doi.org/10.4158/EP09101.ORR

How to cite this article: Lithgow, H., Florida-James, G., Ross, M., Duncan, G., \& Leggate, M. (2021). Exercise acutely increases vitamin $D$ receptor expression in T lymphocytes in vitamin D-deficient men, independent of age. Experimental Physiology, 106,1460-1469. https://doi.org/10.1113/EP089480 